\title{
Estimating the Effectiveness and Feasibility of a Game-based Project for Early Foreign Language Learning
}

\author{
Eleni Griva ${ }^{1} \&$ Klio Semoglou ${ }^{1}$ \\ ${ }^{1}$ Department of Educational Studies, University of Western Macedonia, Florina, Greece \\ Correspondence: Eleni Griva, $3^{\text {rd }}$ km Florina-Niki, 53100 Florina, Greece. E-mail: egriva@uowm.gr
}

Received: June 20, 2012 Accepted: July 6, 2012 Online Published: July 25, 2012

doi:10.5539/elt.v5n9p33 URL: http://dx.doi.org/10.5539/elt.v5n9p33

\begin{abstract}
This paper outlines the rationale for and the purpose of designing and implementing a project aiming to make very young EFL learners develop their language skills through their involvement in interactive psychomotor activities. The project, which is a part of a broader longitudinal project having introduced EFL in the first primary school grade, was implemented in two $2^{\text {nd }}$ grade Greek classrooms with a total of 44 seven year old children. Multisensory teaching was followed through the use of a combination of activities: classroom creative activities included memory and word games, drawings, constructions, role-play games, pantomime as well as songs. In the gym, children participated in physical activities such as races, chases and hopscotch as well as dance and music activities, with the aim to improve their oral communicative skills and creativity. In order to examine the effectiveness and feasibility of the project, an evaluation study was conducted by using a pre- and post- language test and journals kept by the teachers. It was evident that the project had a positive effect on developing very young learners' language skills, and on enhancing their motivation to participate in psychomotor activities.
\end{abstract}

Keywords: English language, physical activities, early EFL learning

\section{Introduction}

\subsection{Foreign Language Learning from a Very Early Age}

The policy of early introduction of foreign languages (FLs) in primary education has been established in Europe over the last two decades. Documentation of the European Commission records the teaching of modern languages to young learners and recommends foreign language (FL) teaching to be provided at the first primary school grades or even from kindergarten in order to allow for foreign languages to be developed at the secondary school level (Commission of the European Communities, 1995). Learning languages contributes to the development of students' multilingual and multicultural awareness (Griva \& Chostelidou, 2011), which enables them to communicate across countries, helps them acquire a wider sense of active citizenship in modern multilingual societies as well as to the development of lifelong positive attitudes to other languages and develop an understanding of their rights and responsibilities as mobile citizens across European countries (Griva, Chostelidou \& Tsakiridou, 2011). Due to the fact that the Council of Europe language policy documents recommend two foreign languages with the aim to allow students to study another language along with English, some early programs have been conducted in a number of languages (Euridyce, 2005). However, the proportion of English compared to other languages has been dynamically dominant worldwide. In many instances, the first foreign language - which is English - is compulsory, and the second one is optional. It is note worthy that in some countries the first foreign language is compulsory from the first grade of primary school or even from pre-school, for example in Luxemburg, Malta, Norway, Belgium, Germany, Italy, Spain and Austria.

A number of studies, which focus on international comparisons of early FL programs designed for young learners (Edelenbos et al, 2006; Nikolov \& Curtain, 2000), revealed important issues in relation to the beneficial aspects of early language instruction practices all over the world. In most studies, experimental programs have produced effective results (e.g. Griva \& Sivropoulou, 2009; Griva, Semoglou \& Geladari, 2010; Moon \& Nikolov, 2000). Students' personal characteristics such as age, motivation, affective factors (Bongaerts, 1999; Singleton, 1989), learning context as well as certain teaching methods and techniques (Ioup, 1995) have proved to have an important impact on language learning. However, the age at which a child should be initially exposed to a second/foreign language has been one of the issues most researched (Singleton, 2003). 
Recent researchers have indicated that the earlier a child is exposed to a second language, in an environment rich in language input and interaction, the better the outcome can be (e.g. Birdsong \& Molis, 2001; Flege, 1999). It has been showed that there is a maturational limit around puberty; beyond this limit, more effort is required for learning a second language (Scovel, 2000). It should be noted that children who are adequately exposed to two languages at an early age experience certain gains compared to monolingual ones, such as communicative flexibility, creativity and high levels of cognitive ability (Curtain \& Pesola, 1988). There is a body of research which revealed various positive advantages of very young FL learners, such as better pronunciation and language performance, as well as school attainment (Krashen \& Terrell 1983; Singleton, 1989). They can also have advantages with respect to their academic achievement, and the development of positive attitudes towards the target language and culture (Dominguez \& Pessoa, 2005; Kumaravadivelu, 2006; Lightbown \& Spada, 2008).

In additon, very young learners have been recorded to present more positive attitudes towards learning foreign languages and be more motivated due to their general positive attitude towards learning and their curiosity, openess and enthusiasm to new experience (Cameron, 2001; Donato et al, 2000; Hurrell \& Satchwell, 1996; Nikolov, 1999; Pinter, 2006). Nevertheless, according to other studies, older learners are thought to be better in some other language areas, such as the use of grammar and metacognitive skills (see Van Patten, 2003).

\subsection{Early Foreign Language Teaching in a Game Based Context}

An early start does not itself guarantee effectiveness, unless certain teaching conditions are created and proper teaching techniques are employed (Blondin et al, 1998). Since learning is perceived as a cognitive, psycho-dynamic and social process (Illeris, 2002), children should be encouraged to learn through collaborative groups that allow for interaction and active engagement. Young children are not aware of the need for learning a FL, however they are more open towards learning languages than adolescents (Brown, 2000). Therefore, the need to communicate in a FL can be created through participation in games and physical activities. It has been revealed that they learn languages more quickly and with less effort and they learn a FL best in a low-anxiety environment. Thus, a meaningful and playful context is necessary for effective language learning, where children can involve many senses.

Thus, a task-based approach should be adopted, where children can learn the target language by interacting communicatively and purposefully, while getting engaged in child oriented tasks. Current studies on language learning follows the premise that children learn best through discovery and experimentation, as well as when they are enjoying themselves (Scott \& Ytreberg, 1994). Activities and tasks should create conditions for exploitation from the part of the children, teacher- student interaction and provision of comprehensible input and processes for engaging that input (Candlin, 2009). Authentic input can provide for the type of environment that is conducive to learning; games, stories and drama tend to be attractive activities for children to participate in without feeling much stress, while being engaged in a natural environment (Tomlinson \& Masuhara, 2009). Children's language acquisition should be a natural process related to all aspects of children's lives (Sawyer \& Sawyer, 1993), since children at this age like routines, familiar situations, repeating rhymes and songs. For this purpose, the selected tasks should be meaningful and help children to make sense of new experiences and construct new input by relating them to what they already know. In addition, children need to get involved in contextualized and comprehensible language experience and acquire deep and multidimensional processing of the target language (Krashen, 1999; Masuhara, 2005; Tomlinson, 2000).

It is widely accepted that interactivity, fantasy, curiosity, challenge and risk are the basic aspects of the physical activities and games. In this vein, learning through playing is the best way to learn a language because it creates emotional attachments and it focuses on children's participation and enjoyment in a non-threatening and relaxed situation (Dryden \& Vos, 1997). Physical games are highly motivating, entertaining and give shy learners an extra opportunity to express themselves (Tuan, Luu Trong \& Nguyen Thi Minh Doan, 2010). Play can a) give children an opportunity for listening and speaking in a meaningful and challenging context (Wright et al, 1984), particularly children with limited language repertoires, by encouraging them to use non verbal communication (Desiatova, 2009). b) stimulate children to listen to game instructions and rules and interact with other peers in a pleasurable low risk context (Tomlinson \& Masuhara, 2009). Furthermore, role play games are activities that provide children with opportunities to practice various language aspects assuming a role, which they may encounter outside the language classroom and draw on whatever resources are available to them (Aldavero, 2008; Livingstone, 1983).

Teaching very young learners should also be supported by using pictures and sounds, as well as rhythm and movement in a relaxed, challenging and multi-sensory context, where children are exposed to a rich, meaningful, and comprehensible input (Dryden \& Vos, 1997; Krashen, 1999; Pavlenko, 2005). The children at this age learn 
better when they feel secure and relaxed, since they need to be engaged both affectively and cognitively in the language experience (Arnold, 1999; Masuhara, 2005; Tomlinson, 2000).

\section{Implementation of EFL Learning Project Based on Physical Activities}

\subsection{Objectives of the Project}

The potential for foreign language learning through physical activities has not thoroughly been explored by researchers or practitioners in the Greek educational system. Having considered the body of research data on the benefits of early FL learning and the advantages of physical games on children's cognitive, linguistic and affective development, a project was designed and implemented with the aim to develop very young children's EFL (English as a Foreign Language) skills through their involvement in interactive physical activities. The main objectives of the project were the following: a) developing children's basic communicative/oral skills in English language; b) enhancing their involvement in learning through their senses by making provision for multi sensory learning.

\subsection{Rationale and Design of the Project}

The project was implemented in two 2nd grade classrooms of a Greek experimental primary school. Twenty two (22) students (mean age $=7.41$ y.o) were assigned to the experimental group and twenty two 22 students (mean age $=7.56$ y.o) to the control group. Both groups were randomly selected and taught English three hours per week, for a period of sixteen weeks. Common topics related to children's everyday routine were used both in the experimental and control class. However, different approaches were employed and implemented in diverse teaching contexts: the control group were taught English in the convention PPP (Presentation- PracticeProduction) context.

On the other hand, the experimental group received English language teaching in a playful context through children's participating in physical activities. Activities were performed in the classroom (one hour per week) and in the school gym (two hours per week). An attempt was made to allow children experience EFL through a variety of physical activities and games in a relaxed and interesting atmosphere, which motivates them to interact with their peers (Paz, 1997). The activities were designed taking into account: a) children's interests, cognitive skills and prior knowledge. b) certain criteria for "good" language learning tasks, such as drawing objectives from learners' communicative needs, allowing for different solutions depending on learners' skills, involving learners' contribution and affect, being challenging but not threatening, involving language use in the 'solution' of a 'problem', providing opportunities for language practice (Candlin, 2009). This EFL game-based project considered the specific characterists and needs of the target group at cognitive, psychomotor and social level It also took into consideration the fact that children could develop their language skills through exercising motor skills in a 'non-threatening' environment that lowers affective filter, and makes them feel motivated, secure and successful (Brown, 2000). A wide variety of print and other symbolic forms were employed in order to increase the amount of labelling in the environment; the use of flashcards, pictures and objects were adopted by the teachers to support explanations and describe games, events and actions. It is believed that when children are exposed in such a context, they respond both physically and verbally in a meaningful learning context. In some cases, demonstrations were used to help children understand the game and follow its rules.

Physical activities and role play games can contribute to children's psychomotor development, foster cooperation and problem solving as well as contribute to creative thinking. Through the specific programme an attempt was made to help children build on their own creativity and enthusiasm in order to develop a positive attitude towards physical activity and learning a second language. Moreover, since learning is holistic and related to particular experiences in children's lives, the project aimed at offering them relevant learning experiences in a communicative context with topics and language functions being related to their everyday lives and routines.

\section{Evaluation of the Effectiveness and Feasibility of the Game-based Project}

In order to examine the effectiveness and feasibility of the project and its impact on children's oral skills development, an evaluation study was designed and conducted with the purpose to answer the following questions:

a. Could children's listening and speaking skills be developed in a game-based supportive classroom environment?

b. What was the instructional context and what was children's participation in physical activities and role play games?'

\subsection{Instruments}

A combination of the following quantitative and qualitative methods was employed for the evaluation of the 
project:

1) pre- and post-test measurements of foreign language achievement, which used the same components, were administered to the children individually. The measurements referred to the same skills, so that we could have the best possible information about the influence and the effectiveness of the project. The pre-test was administered after the completion of the first, 'warm-up', phase to determine children's oral language skills before the basic intervention; the post-test was administered after the intervention had terminated.

The component parts of the test were the following:

(a) Word production. The children were presented with a poster, including various events; then, they were encouraged to recall and pronounce as many words included in the poster, as possible.

(b) Understanding simple events and pointing them to the poster. This part of the test consisted of ten (10) items including the description of simple events. While the researcher described some simple events, the children had to locate these events in the poster. Two (2) points were scored to the children being able to locate an event by themselves, one (1) point was scored to the children being able to locate an event with the researcher's help and zero (0) when they couldn't locate an event.

(c) Producing a word within a sentential context. This part of the test included five items; the score of each item ranged from zero to two points, as in part (b). The researcher initiated a simple phrase, by pointing to a certain place in the poster, and the children had to complete the phrase by using the correct target word or phrase.

(d) Understanding language functions and performing. This part of the test consisted of ten items; the score of each item ranged from zero to two points, as in parts (b) and (c). The researcher gave children directions to perform certain movements (e.g., 'jump', 'run', 'go to ...', 'come here') and the children had to carry out these actions.

2) Journals were kept by the teachers once a week in order to reflect on learning and teaching issues in relation to the game-based context. Writing about teaching in a journal can help them organize thoughts into more systematic reflections on their work (see Farrell, 2004). When used by teachers/researchers as a means for data collection, journals allow them to come closer and critically investigate their work (McDonough \& McDonough, 1997). According to some other researchers (Holly, 1989; Mackey \& Gass, 2005) journals have been proved to be a flexible tool for documenting classroom events and teaching episodes and self-evaluation.

The 'reflective journal' was used in the present study as an instrument of 'on-going' evaluation of the feasibility and effectiveness of the EFL game-based project. It was designed and applied with the purpose to gain an in-depth understanding of the implementation and monitoring of the project, since it was regarded as a means of generating questions about teaching and learning processes during the project. Thus, the focus was not only on reporting data of the intervention process, but on reflecting on students' behavior, motivation and stances developed throughout the implementation of the project.

A total of sixteen (16) journal entries, based on a list of reflection questions, were kept by the teachers during the project. The structure of the journal was based on the "reflection questions to guide journal entries" provided by Richards and Lockhart (1994). The following reflective processes have an important role to play: a) describing events and procedures, b) articulating and rationalizing concerns, c) exploring solutions, d) deciding on actions and e) describing and evaluating progress.

The questions included in the journal were divided into two main axes a) questions related to teacher including lesson planning, techniques and materials used, problems encountered and suggestions for possible changes. b) questions related to children's behavior during the project.

\section{Results}

\subsection{Results of the Pre and Post-test Measurements}

The data analysis was conducted using SPSS (ver. 18.0). Reliability analysis was performed with Cronbach's $\mathrm{a}=0,7496$. The dependent variables were tested for normality using Kolmogorov-Smirnov test and were found to be normally distributed ( $\mathrm{p}>05$ ). A $2 \mathrm{X} 2$ repeated measures ANOVA with factor 'time' (pre - post) and factor 'group' (control - experimental) was performed for each of four dependent variables a) Word Production, b) Understanding Simple Events and Pointing to the Right Place in the Poster, c) Producing a Word within a Sentential Context and d) Understanding language Functions and Perform.

The mean scores of children's performance in the pre and post test measurements suggested a strong effect of a) the game-based intervention on the experimental group and b) the PPP intervention on the control group, since both groups considerable progress and performed significantly better in the post test in every variable. However, 
it was revealed that the children of the experimental group scored higher than those of the control group (Table $1)$.

Table 1. Mean scores (and standard deviations) of children's performance in the pre- and post-test measurements

\begin{tabular}{lllll}
\hline & pre-test & & post-test \\
group & $\begin{array}{l}\text { experimental } \\
\text { experimental }\end{array}$ & control & control \\
& 11.05 & 10.68 & 23.95 & 21.86 \\
Word Production & $(6.08)$ & $(5.19)$ & $(6.15)$ & $(7.02)$ \\
Understanding Simple Events and & 9.09 & 9.41 & 13.55 & 12.77 \\
$\begin{array}{l}\text { Pointing to the Right Place } \\
\text { Producing a Word within a }\end{array}$ & $(3.07)$ & $(3.66)$ & $(3.20)$ & $(3.75)$ \\
Sentential Context & 1.32 & 1.32 & 4.09 & 4.04 \\
Understand language Functions and & $(1.56)$ & $(1.70)$ & $(1.95)$ & $(1.91)$ \\
Perform & 3.18 & 2.91 & 7.54 & 6.09 \\
& $(2.36)$ & $(2.02)$ & $(1.84)$ & $(2.72)$ \\
\hline
\end{tabular}

a) Word Production: The analysis indicated that there was a significant main effect for factor 'time' $[\mathrm{F}(1,42)=160,645, \mathrm{p}<.005]$. However, there was no significant interaction between the two factors ('time' 'group'). More specifically, the mean score in the pre-test was 11.05 words $(\mathrm{sd}=6.08)$ for the experimental group and $10.68(\mathrm{sd}=5.19)$ for the control group. In the post-test, the mean score of the words pronounced correctly by the children of the experimental group was $23.95(\mathrm{sd}=6.15)$ and 21.86 for the children of the control group $(\mathrm{sd}=7.02)$ (Figure 1).

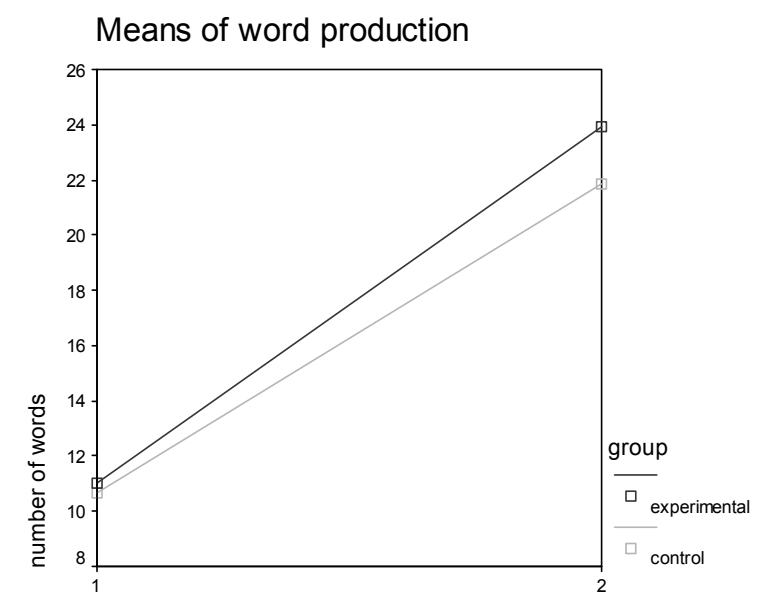

Figure 1. The mean scores of word production in the first part of pre- and post-test

b) Understanding Simple Events and Pointing to the Right Place in the Poster. The results of the ANOVA indicated a significant main effect for factor 'time' $[\mathrm{F}(1,42)=336.182, \mathrm{p}<.005]$, and no significant interaction between the two factors. The total effect of the intervention on children's performance was obvious, as during the pre-test none of the children could locate all the events in the poster by themselves. On the contrary, during the post-test the majority of the children were able to locate the events in the poster by themselves (74\%) or with the researcher's help (26\%). The mean score for the children of the experimental group was 9.09 (sd=3.07) in the pre test and $13.55(\mathrm{sd}=3.20)$ in the post test. Also, the children of control group scored statistically better in the post test $(\mathrm{m}=12.77, \mathrm{sd}=3.75)$ than in the pre-test $(\mathrm{m}=9.41, \mathrm{sd}=3.66)$ (Figure 2$)$. 


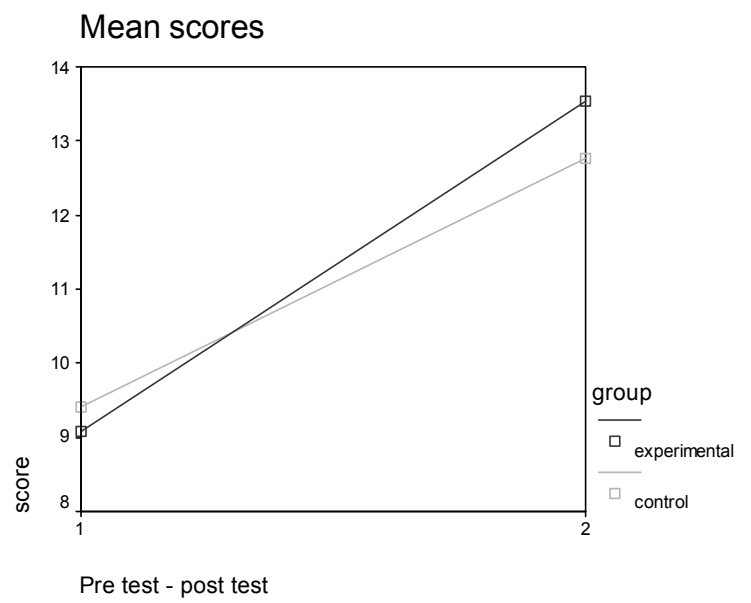

Figure 2. The mean scores of the second part of pre- and post-test

c) Producing a Word within a Sentential Context. In this part of the test the researcher initiated a simple phrase, by pointing to a certain place in the poster, and the children had to complete the phrase by using the correct target word or phrase. The results of the ANOVA indicated a significant main effect for factor 'time' $[F(1,42)=137.500, p<.005]$, and no significant interaction between the two factors. The mean score for the children of the experimental group was $1.32(\mathrm{sd}=1.56)$ in the pre test and $4.09(\mathrm{sd}=1.95)$ in the post test. Also, the children of control group scored statistically better in the post test $(\mathrm{m}=4.04, \mathrm{sd}=1.91)$ than in the pre-test $(\mathrm{m}=1.32, \mathrm{sd}=1.70)$ (Figure 3$)$. More precisely, during the pre-test only 15 children (34.1\%) of both groups were able to continue more than one of phrases by using the correct word and pointing to the right place of the poster. On the contrary, the results of the post-test indicated that all children of both groups were able to complete most of the phrases by using the correct target word or phrase. It is note worthy that although 10 children (22.7\%) scored zero in the pre-test, they responded correctly in the post-test.

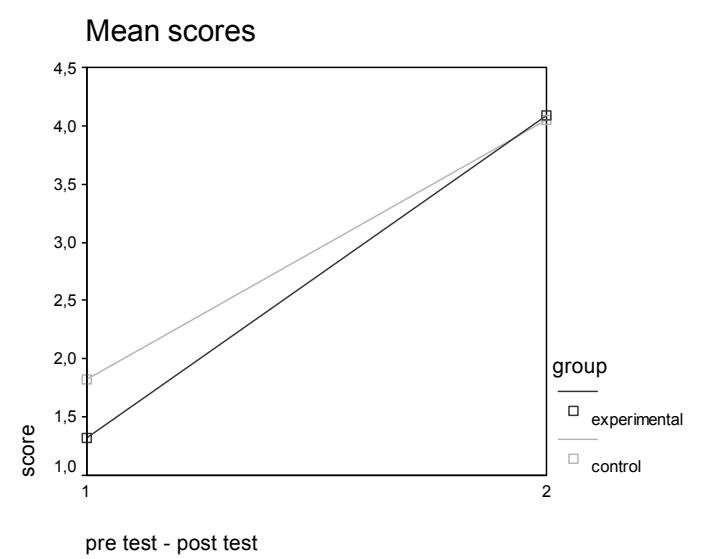

Figure 3. The mean scores of the third part of pre- and post-test

d) Understanding language Functions and Performing. The ANOVA analysis for this variable indicated a significant main effect for factor 'time' $[\mathrm{F}(1,42)=313.136, \mathrm{p}<.005]$, and no significant interaction between the two factors. The mean score for the children of the experimental group was $3.18(\mathrm{sd}=2.36)$ in the pre test, and $2.91(\mathrm{sd}=2.02)$ in the post test. Also the children of the control group scored statistically better in the post test $(\mathrm{m}=7.54, \mathrm{sd}=1.84)$ than in the pre-test $(\mathrm{m}=6.09, \mathrm{sd}=2.72)$ (Figure 4$)$. It is worth mentioning that $7(15.9 \%)$ of the total number of the children answered incorrectly in the pre-test when the researcher gave them directions to perform certain movements (e.g., 'jump', 'run', 'go to ...', 'come here'). Furthermore, 28 (63.6\%) children of both groups answered correctly after the researcher's help. On the other hand, only one child from the control group $(2.3 \%)$ responded incorrectly in every item in the post-test, while all the children from the experimental group were able to perform correctly all movements by themselves or with the researcher's help. 


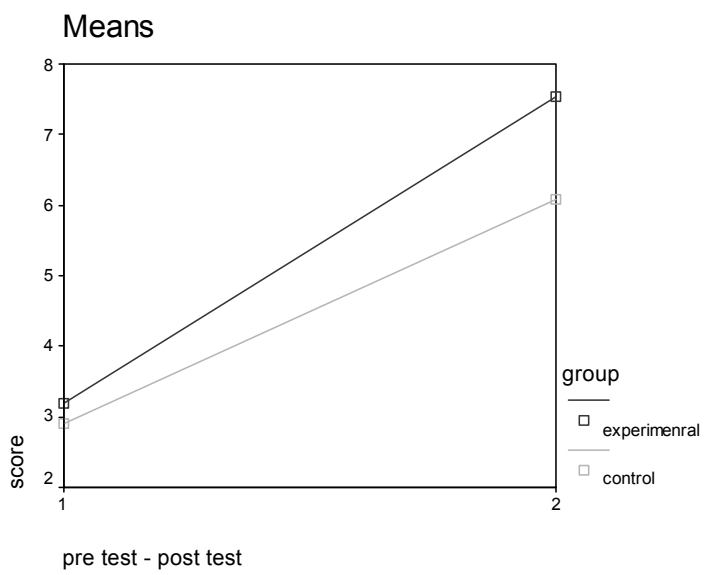

Figure 4. The mean scores of the fourth part of pre- and post-test

\subsection{Results of Journals}

Concerning the analysis of the journals, basic typologies emerged, so as to classify similar categories and subcategories, giving further meanings and understanding of the content of the field notes (Bailey, 1994).

From the analysis of the extracts, four basic typologies emerged so as to classify similar categories and sub-categories: a) teaching procedure, b) teacher's role, c) student's behavior and d) problems encountered. The classification scheme used in this research depended upon what the researchers thought it was meaningful in the setting (Bailey 1994) (Table 2).

Table 2. Typologies, categories and subcategories of Journal entries

\begin{tabular}{lll}
\hline Categories & Subcategories \\
\hline Teaching procedure & 1. Techniques & A. Physical activities \\
& & B. Question and answer technique \\
& C. Dramatization-role play \\
\cline { 2 - 3 } 2. Materials and aids & D. Games \\
& E. Multisensory learning \\
\cline { 2 - 3 } 3. Communication & A. Flashcards and posters \\
& B. Realia \\
& C. Constructions, puzzles and Drawings \\
& D. Computer \\
& A. Use of target language \\
& B. Use of mother tongue \\
& C. Non-verbal communication \\
\cline { 2 - 3 } 4. Forms of work & D. Interaction within group \\
& E. Interaction between groups \\
& F. Teacher-student interaction \\
\cline { 2 - 3 } 5. Learning Outcome & A. Teacher-classroom \\
& B. Pair work \\
& C. Group work \\
& D. Movement and play \\
& A. Understanding rules \\
& B. Enjoyment and amusement \\
& C. Learning new words while playing \\
& D. Recalling and use of new words/phrases \\
& E. Verbal-nonverbal communication \\
& F. Spontaneous language experience \\
& G. Creativity \\
\hline
\end{tabular}




\begin{tabular}{|c|c|c|}
\hline \multirow[t]{3}{*}{ Teacher's Role } & 1. Encouragement & $\begin{array}{l}\text { A. Encouraging children to use their full potential } \\
\text { B. Encouraging children to get involved in role play } \\
\text { C. Encouraging children to participate in motor activities } \\
\text { D. Encouraging interaction } \\
\text { E. Encouraging creativity }\end{array}$ \\
\hline & 2. Prompting/ reinforcement & $\begin{array}{l}\text { A. Challenging them to participate actively } \\
\text { B. Challenging them to communicate in the target } \\
\text { language } \\
\text { C. Reinforcing them to participate in dramatization } \\
\text { D. Reinforcing them to take risks } \\
\text { E. Children's drawings } \\
\text { F. Stimulate children's affective and cognitive } \\
\text { engagement }\end{array}$ \\
\hline & 3. Guidance & $\begin{array}{l}\text { A. Clear directions } \\
\text { B. Guiding them to practice certain words/phrases } \\
\text { C. Guiding them to work in groups } \\
\text { D. Guiding them to cooperate with peers } \\
\text { E. Supportive, non threatening environment }\end{array}$ \\
\hline \multirow[t]{3}{*}{ Children's Behc } & $r$ 1. Interest & $\begin{array}{l}\text { A. Interaction within group } \\
\text { B. Interaction in role play } \\
\text { C. Showing commitment } \\
\text { D. Interest in movement activities }\end{array}$ \\
\hline & 2. Participation & $\begin{array}{l}\text { A. Spontaneous participation in interactive activities } \\
\text { B. Spontaneous participation in movement activities } \\
\text { C. Spontaneous participation in dramatization } \\
\text { D. Helping each other during constructions } \\
\text { E. Participation in card games }\end{array}$ \\
\hline & 3. Positive attitudes & $\begin{array}{l}\text { A. Active role } \\
\text { B. Participation and cooperation } \\
\text { C. Reduction of anxiety } \\
\text { D. General enthusiasm and excitement } \\
\text { E. Enjoying physical activities } \\
\text { F. Enjoying dramatizing }\end{array}$ \\
\hline \multirow[t]{2}{*}{$\begin{array}{l}\text { Problems } \\
\text { encountered }\end{array}$} & 1. Teacher & $\begin{array}{l}\text { A. Classroom management } \\
\text { B. Teacher's anxiety } \\
\text { C. Time management } \\
\text { D. Need for substitution of certain activities }\end{array}$ \\
\hline & 3. Student & $\begin{array}{l}\text { A. Difficulties in understanding new rules } \\
\text { B. Difficulties in recalling and using words/phrases } \\
\text { C. Difficulties in understanding new vocabulary } \\
\text { D. Overreliance on gestures }\end{array}$ \\
\hline
\end{tabular}

\subsubsection{Teaching Procedure}

Multisensory learning was attempted in a supportive classroom context, where a variety of physical activities, question and answer technique, role play games, constructions and drawings were included. The children were offered the opportunity to familiarize themselves and work with a great variety of materials such as pictures, realia, drawings, photocopied pictures, puzzles, either individually or by the whole class.

In the first stage of every teaching session, the teacher worked with the whole class, pointing at the words written under the flashcards to integrate reading and help students "understand conventions of written language". Moreover, through the use of 'question and answer' technique children were offered the opportunity to practice a certain range of vocabulary, as well as wh-questions and answer patterns. By pantomiming words or phrases, the teacher tried to familiarize students with the meaning of the words they were going to use in various physical activities. In the main stage of the teaching session, physical activities were the basic technique performed in a natural, non-threatening environment where the children experienced FL spontaneously.

The target language was mostly used by the teacher in order to provide children with ample opportunities for practice. Furthermore, non-verbal communication was used as a means of facilitating understanding of difficult parts of the game/physical activity. As far as the use of mother tongue is concerned, it was recorded to be the main form of communication among children, during group and pair work, acting as a mediation activity that helped them to clarify any difficult parts of the games.

\subsubsection{Teacher's Role}


During the implementation of the project, the teacher assumed a flexible and encouraging role by acting as a coordinator 'trying to provide specific instructions regarding the procedure students should follow', and helping students understand the purpose of the activities. Children were constantly encouraged to participate and ask questions, while emphasis was placed on the creation of a supportive and interactive environment.

In a prompting and playful classroom environment, the children were encouraged to use their full potential while working in pairs and groups, play with words and communicate in simple phrases and words. It was also recorded that flashcards, posters, puzzles and constructions were used in every session, offering children the chance to deal with concepts by exploring and working with a variety of materials. During this process, the teacher circulated among groups, asked them questions and encouraged them to give an answer. There was a remarkable attempt to a) motivate children to cooperate, b) practice certain words or phrases and c) make them be zealous for performing a game or a group activity. In the course of the project, it was recorded that teacher's guidance was on gradual 'decrease', since the children were more flexible, communicative and willing to participate.

At the end of each teaching session, certain suggestions on the improvement of the teaching procedure were made. Emphasis was placed on teacher's flexible role in order to foresee 'unpredictable situations' or improve the management of the activities designed. Moreover, the modification of the $5^{\text {th }}$ lesson plan was suggested so as to 'follow students' linguistic level', while a change in the lesson plan of the $9^{\text {th }}$ lesson was considered to be necessary. Finally, suggestions were made regarding classroom management, which were proven to be valuable and allowed teacher to understand and prevent problems and reflect on her role.

\subsubsection{Students' Behavior}

The children were particularly interested in participating in most activities and managed to overcome anxiety problems, since the degree of communication among them was considered to be satisfying mainly because of the content and topics of the activities. In the course of the intervention, the children showed interest in activities related with exploring and working with familiar classroom equipment and materials, flashcards and puzzles in a variety of ways in order to develop concepts and to learn certain vocabulary. Creative 'word' play was promoted and, as the sessions proceeded, children experienced growth in pronouncing words and understanding word meanings. Concerning their attitude towards activities, they exhibited excitement when gathering to enact a role play activity or to participate in a physical activity. It was evident that the children rarely lost focus or interest in these activities and they greatly enjoyed the hands-on and movement activities. Role play activities provided motivation in language learning and permitted shy children to overcome their inhibition in situations which were not 'threatening' (Table 2).

In relation to verbal communication, the children listened to the teacher, with increasing attention, they understood simple oral phrases and enjoyed listening to and responding to the other peers. They were able to comprehend certain phrases and responded in single words or brief phrases to some questions, especially 'what' and 'where' questions. In addition, they used simple phrases to play and pretend, with increasing ease, during games. A steady increase in understanding, producing and communicating in the target language was recorded.

\subsubsection{Problems Encountered}

However, in the course of the intervention both the teacher and the children experienced some problems and encountered some difficulties. Regarding the teacher, she faced some problems related to classroom management, time management and redesign of some activities. Concerning the children, they encountered problems in understanding and using new words, in understanding the rules and answering questions about the content of the story. Participation was reported to be low during the first teaching session and there was a problem in understanding the fifth lesson, as 'it was too difficult for their level, including much information'.

In addition, some children experienced certain oral language difficulties: they encountered more difficulties in recalling and using the right word in order to produce spoken language rather than comprehension problems. That is, they encountered problems with producing language in social contexts rather than understanding. In some cases, overreliance on gestures to communicate was observed and recorded because of the inadequacy in using specific vocabulary. It is worth mentioning that three children faced difficulties in interactive play with some peers.

\section{Discussion}

The purpose of this paper was to present a game-based framework of teaching EFL, which was designed to meet the needs of a specific group of seven year old Greek students. Drawing from the findings of the study, it could be concluded that the project proved to be effective for the enhancement of young children's oral skills in the 
target language. The activities proved to be an appealing teaching 'tool' which promotes cooperation, collaboration, and contributed to the development of FL skills, as well as emotional and social skills. They provided children with a rich experience of language in use through their having to listen to instructions and rules of the games and interacting with their classmates. It was revealed that both 'in' and 'out' of the classroom games created a non-threatening and interactive environment and encouraged active participation; these findings are in vein with a number of other studies reported in the literature (Deesri, 2002; Gaudart 1999; Shie, 2003).

Specifically, in relation to the pre and post test measurements, the mean scores of children's performance suggested a strong effect of the game-based intervention on the experimental group, since the children showed considerable progress and performed significantly better in the post test in every variable. In addition, it was revealed that the children of the experimental group scored higher than those of the control group.

Based on the experimental students' responses to the questionnaire, enthusiasm and interest in communicating in EFL through their participation in interactive and movement activities were recorded. Also, their eagerness to participate in such a project was showed and their willingness to be taught the target language in a game-based context was expressed. Comparably, findings from the journals indicated that almost all children responded positively and got involved actively in all stages of the intervention sessions. In a context with three basic characteristics - physical movement, simulation and creativity- FL learning was an active and spontaneous experience, where children showed a tendency to play with and practice target language elements. It was recorded that the emphasis on holistic learning and multi-sensory inputs fostered and sustained children's motivation. They were encouraged to listen carefully, understand simple instructions, play games in a stimulating context, take part in a short conversations using familiar language, integrate verbal and non verbal aspects of communication and have some understanding of how language works. In such a context, the focus was on children's developing receptive and productive skills, rather than focusing on learning particular words or phases in the target language.

\section{Conclusion}

The project had a positive effect on classroom dynamics, thus facilitating cooperation within and between groups, where students had the opportunity to use language to express various emotions, to solve problems, to make decisions and to socialize (Blatner, 2009). Through playing with peers, children learned to share, cooperate, and control aggression by helping each other to problem solving. Communication among young learners was fostered and a variety of opportunities was provided to children to use the target language in 'real' situations. More precisely, participating in physical activities and role play games provided a real reason for children to use the target language, since they were engaged in the pragmatic and functional use of FL for meaningful communicative purposes. Children were encouraged to practice the realistic use of language to communicate in a more relaxed, contextualized and creative framework. It is also worth mentioning that, since physical games did not require only a verbal response, the children with limited language, as well as the shy and less confident children, were encouraged to participate, express themselves and communicate, even using non verbal communication (body movement and facial expression) (Desiatova, 2009).

This game-based project was revealed to be workable to the specific group of very young learners. The overall positive effects of the use of physical activities and role play games in EFL could have implications for teachers and curricula designers. As the sample size of the present intervention was small, it should be replicated with a larger sample size, to a greater number of primary school classrooms, and also with young learners of different demographic characteristics in order to increase the generalizability of the findings. Moreover, in order to achieve highly valued advantages of an early start in EFL learning there is the need to create a supportive environment and establish continuity from one year to the other. For this reason, an extension of the programme with the same children in the second grade would guarantee continuity and lead to gaining a more complete picture of the effectiveness of the game-based project.

\section{References}

Aldavero, V. A. (2008). Drama in the development of oral spontaneous communication, Encuentro, 17, 40-43.

Arnold, J. (1999). Affect in Language Learning. Cambridge, UK: Cambridge University Press.

Bailey, K. (1994). Typologies and Taxonomies: An Introduction to Classification Techniques. London: Sage Publications.

Birdsong, D., \& Molis, M. (2001). On the evidence for maturational constraints in second-language acquisition. Journal of Memory and Language, 44, 235-49.

Blatner, A. (2009). Role Playing in Education. Retrieved from www.blatner.com/adam/pdntbk/ rlplayedu.htm 
Bongaerts, T. (1999). Ultimate attainment in L2 pronunciation: The case of very advanced late L2 learners. In D. Birdsong (Ed), Second Language Acquisition and the Critical Period Hypothesis (pp. 33-159). New Jersey, NJ: Lawrence Erlbaum.

Brown, H. D. (2000). Principles of Language Learning and Teaching ( $5^{\text {th }}$ ed.). New York: White Plains, Longman.

Cameron, L. (2001). Teaching Languages to Young Learners. Cambridge: Cambridge University Press.

Candlin, Ch. (2009). Towards task-based language learning. In K.V den Branden, M. Bygate, \& J. Norris (Eds), Task-based Language Teaching. Amsterdam: J. Benjamins Publications Company.

Commission of the European Communities. (1995). White Paper on Education and Training, Teaching and Learning, Towards the Learning Society. Brussels: CoEC.

Curtain, H. A., \& Pesola, C. A. (1988). Languages and Children - Making the Match. Reading: Addison-Wesley Publishing Company.

Deesri, A. (2002). Games in the ESL and EFL class. The Internet TESL Journal. Retrieved from http://iteslj.org/Techniques/Deesri-Games.html

Desiatova, L. (2009). Using different forms of drama in the EFL classroom. Humanising Language Teaching, 11(4), ISSN: 1755-9715.

Domínguez, R., \& Pessoa, R. (2005). Early versus late start in foreign language education: Documenting achievements. Foreign Language Annals, 38, 473-483.

Donato, R., Tucker, G. R., Wudthayagorn, J., \& Igarashi, K. (2000). Converging evidence: Attitudes, achievements, and instruction in the later years of FLES. Foreign Language Annals, 33, 377-93.

Dryden, G., \& Vos, J. (1997). The Learning Revolution. Auckland: The Learning Web.

Edelenbos, P., Johnstone, J., \& Kubanek, A. (2006). The main pedagogical principles underlying the teaching of languages to very young learners: Languages for the children of Europe. European Commission.

Eurydice. (2005). Key Data on Teaching Languages at School in Europe. Brussels: The European Unit.

Farrell, T. (2004). Reflective practice in action: 80 reflection breaks for busy teachers. California: Corwin Press.

Flege, J. E. (1999). Age of learning and second language speech. In D. Birdsong (Eds.), Second Language Acquisition and the Critical Period Hypothesis (pp. 101-31). New Jersey: Erlbaum.

Gaudart, H. (1999). Games as teaching tools for teaching English to speakers of other languages. Simulation and Gaming, 30(3), 283-291.

Griva, E., \& Sivropoulou E. (2009). Implementation and evaluation of an early foreign language project in kindergarten. The Early Childhood Journal, 37(1), 79-87. http://dx.doi.org/10.1007/s10643-009-0314-3

Griva, E., Semoglou, K., \& Geladari, A. (2010). Early foreign language learning: implementation of a project in a game -based context. Selected Volume: Procedia Social and Behavioral Sciences, Elsevier, 2, 3700-3705. http://dx.doi.org/10.1016/sbspro.2011.02.002

Griva, E., Chostelidou, D., \& Tsakiridou, E. (2011). Assessment of metalinguistic awareness and strategy use of young EFL learners. In L. Warfelt (Ed.), Language Acquisition (pp. 56-64). Nova Science publishers.

Griva, E., \& Chostelidou, D. (2011). English Language Teachers' conceptions and attitudes to multilingual development in Education. Selected Volume: Procedia Social and Behavioral Sciences, ELSEVIER. http://dx.doi.org/10.1016/sbspro.2010.03.575.

Holly, M. L. (1989). Reflective writing and the spirit of inquiry. Cambridge Journal of Education, 19(1), 71-80.

Hurrell, A., \& Satchwell, P. (1996). Reflections on Modern Languages in Primary Education: six UK Case Studies. London, UK: CILT.

Illeris, K. (2002). The Three Dimensions of Learning: Contemporary Theory in the Tension Field between the Cognitive, Emotional and Social. Roskilde, Denmark: Roskilde University Press.

Ioup, G. (1995). Evaluating the need for input enhancement in post-critical period language acquisition. In D. Singleton, \& Z. Lengyel (Eds.), The age factor in second language acquisition (pp. 95-123). Clevedon, UK: Multilingual Matters.

Krashen, S. D., \& Terrell, T. D. (1983). The Natural Approach: Language Acquisition in the Classroom. San Francisco: The Alemany Press. 
Krashen, S. (1999). Three Arguments against whole language and why they are wrong. Portsmouth NH: Heinemann.

Kumaravadivelu, B. (2006). Understanding language teaching from method to post method. New Jersey Mahwah: Lawrence Erlbaum Associates.

Lightbown, P., \& Spada, N. (2006). How Languages are Learned. London: Oxford University Press.

Livingstone, C. (1983). Role-play in Language Learning. Singapore: Longman.

Mackey, A., \& Gass, S. M. (2005). Second Language Research: Methodology and Design. New Jersey: Lawrence Erlbaum.

Masuhara, H. (2005). Helping learners to achieve multi-dimensional representation in L2 reading. Folio, 9(2), 6-9. http://dx.doi.org/10.1093/elt/ccn028

McDonough, J., \& McDonough, S. H. (1997). Research Methods for English Language Teachers. London: Edward Arnold.

Moon, J., \& Nikolov, M. (2000). Research into teaching English to young learners. Pécs: University Press Pécs.

Nikolov, M., \& Curtain, H. (2000). An Early Start: Young Learners and Modern Languages in Europe and Beyond. Council of Europe: European Centre for Modern Languages.

Nikolov, M. (1999). 'Why do you learn English? Because the teacher is short'. A study of Hungarian children's foreign language. Language Teaching Research, 3(1), 33-56.

Pavlenko, A. (2005). Emotions and Multilingualism. Cambridge, UK: Cambridge University Press.

Pinter, A. (2006). Teaching Young Language Learners. Oxford: Oxford University Press.

Richards, J., \& C. Lockhart. (1994). Reflective Teaching in Second Language Classrooms. Cambridge: Cambridge University Press.

Sawyer, W. E., \& Sawyer, J. C. (1993). Integrated Language Arts for Emerging Literacy. New York: Delmar.

Scott, W., \& Ytreberg L. H. (1994). Teaching English to Children. London: Longman.

Scovel, T. (2000). A critical review of the critical period hypothesis. Annual Review of Applied Linguistics, 20, 213-23.

Shie, J. S. (2003). Aspects of EFL games. Taipei: The Crance Pulishing Company.

Singleton, D. (1989). Language Acquisition: The Age Factor. Clevedon, UK: Multilingual Matters.

Singleton, D. (2003). Critical period or general age factor(s)? In M. P. García Mayo, \& M. L. García Lecumberri, Age and the Acquisition of English as a Foreign Language (pp. 3-22). Clevedon, UK: Multilingual Matters.

Tomlinson, B., \& Masuhara, H. (2009). Playing to learn: a review of physical games in second language acquisition. Simulation \& Gaming. http://dx.doi.org/10.1177/1046878109339969. http://sg.sagepub.com

Tomlinson, B. (2000). A multi-dimensional approach. The Language Teacher, 23, 25-27.

Tuan, Luu, Trong, \& Nguyen, Thi Minh, Doan. (2010). Teaching English grammar through games. Studies in Literature and Language, 1(7), 61-75.

Van Patten, B. (2003). From Input to Output: a Teacher's Guide to Second Language Acquisition. New York: McGraw-Hill.

Wright, A., Betteridge, D., \& Buckby, M. (1984). Games for Language Learning. Cambridge: Cambridge University Press. 